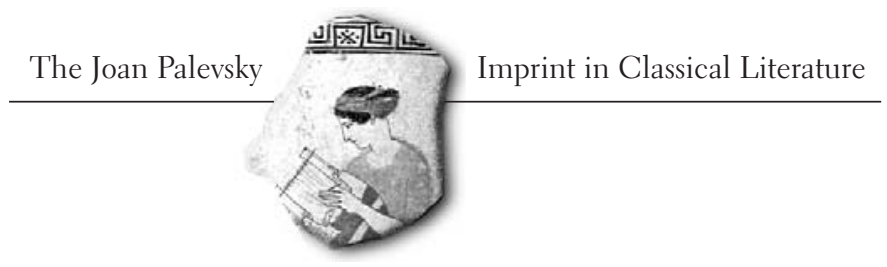

In honor of beloved Virgil—

"O degli altri poeti onore e lume ..."

-Dante, Inferno 
The publisher gratefully acknowledges the generous contribution to this book provided by the Classical Literature Endowment Fund of the University of California Press, which is supported by a major gift from Joan Palevsky. 
Citizen Bacchae 
This page intentionally left blank 


\section{Citizen Bacchae}

Women's Ritual Practice in Ancient Greece

Barbara Goff

UNIVERSITY OF CALIFORNIA PRESS

Berkeley Los Angeles London 
University of California Press

Berkeley and Los Angeles, California

University of California Press, Ltd.

London, England

(C) 2004 by

The Regents of the University of California

Library of Congress Cataloging-in-Publication Data

Goff, Barbara E.

Citizen Bacchae : women's ritual practice in ancient Greece / Barbara Goff.

p. $\mathrm{cm}$.

Includes bibliographical references and index.

ISBN $0-5$ 20-23998-9 (cloth : alk. paper).

1. Greek literature-History and criticism. 2. Rites and

ceremonies in literature. 3. Religion and literature-Greece.

4. Women-Religious life-Greece. 5. Women and literature-

Greece. 6. Rites and ceremonies-Greece. 7. Religion in

literature. 8. Women in literature. 9. Women-Greece. I. Title.

PA3015.W65 G65 2004

$880.9^{\prime} 355-\mathrm{dc} 21$

2003011740

Manufactured in Canada.

$\begin{array}{llllllllll}13 & 12 & 11 & 10 & 09 & 08 & 07 & 06 & 05 & 04\end{array}$

$\begin{array}{llllllllll}10 & 9 & 8 & 7 & 6 & 5 & 4 & 3 & 2 & 1\end{array}$

The paper used in this publication is both acid-free and totally chlorine-free (TCF). It meets the minimum requirements of ANSI/NISO Z39.48-1992 (R 1997) (Permanence of Paper). (-) 
To Michael

sine quo non 
This page intentionally left blank 